\title{
Kualitas Fisik Kompos dengan Pemberian Isi Rumen Sapi dan Aplikasinya pada Perkecambahan Jagung
}

\section{Physical Quality of Compost with The Giving of Cow Rumen Contents and Its Application on Maize Germanation}

\author{
N. Hidayati* dan D. K. Agustina \\ Program Studi Peternakan, Fakultas Pertanian, Universitas Madura \\ *E-mail: nurul@unira.ac.id \\ (Diterima: 14 November 2018; Disetujui: 11 Februari 2019)
}

\begin{abstract}
ABSTRAK
Isi rumen mengandung mikroba yang sangat besar, limbah ini sebenarnya sangat potensial bila dimanfaatkan sebagai starter. Pemberian isi rumen sapi terhadap pembuatan pupuk kompos dan kualitas pupuk kompos yang dihasilkan masih perlu dikaji. Sehingga tujuan penelitian ini untuk mengetahui pengaruh pemberian isi rumen sapi terhadap kualitas fisik pupuk kompos. Penelitian ini dilakukan dengan metode percobaan (eksperimen) menggunakan Rancangan Acak Lengkap (RAL) dengan 5 perlakuan dan 3 ulangan. Perlakuannya yaitu Kontrol (P0): jerami dan kotoran sapi tanpa isi rumen sapi, P1-P4: jerami dan kotoran sapi serta isi rumen diberikan berturut-turut pada kompos umur 0, 10, 20, dan 30 hari. Perbandingan jerami dan kotoran sapi yang digunakan yaitu 1:1 (b/b), serta 10\% isi rumen. Pengamatan dilakukan pada sifat fisik kompos, bobot basah dan bobot kering kompos, serta uji kualitas pupuk kompos pada perkecambahan jagung. Berdasarkan hasil penelitian pemberian isi rumen sapi pada saat pengomposan mempengaruhi sifat fisik dari kompos yaitu suhu, kelembaban, dan tekstur kompos yang terlihat pada $\mathrm{P} 1-\mathrm{P} 4(\mathrm{P}<0.05)$, namun untuk $\mathrm{pH}$ dan warna kompos sama. Bobot basah dan bobot kering kompos lebih tinggi pada perlakuan yang diberi isi rumen sapi pada P1-P4 ( $\mathrm{P}<0.05)$, namun kadar air kompos sama. Pemberian kompos isi rumen pada biji jagung tidak dapat meningkatkan persentase perkecambahan dan tinggi benih jagung. Kompos yang diberi isi rumen sapi nyata lebih bagus kualitasnya dibandingkan dengan kompos tanpa isi rumen sapi.
\end{abstract}

Kata kunci: isi rumen sapi, kualitas fisik, pengomposan, perkecambahan jagung, pupuk organik

\section{ABSTRACT}

The contents of the rumen contained very large microbes, this waste was actually very potential if utilized as a starter. The giving of cow rumen contents to the compost making and the quality of the compost produced still needed to be studied. So the purpose of this research was to know the effect of giving of cow rumen contents to the physical quality of compost. This research was conducted using experimental methods (experiments) and using a Completely Randomized Design (CRD) with 5 treatments and 3 replications. The treatment was Control (P0): straw and cow dung without the contents of cow rumen, P1-P4: straw and cow dung and rumen contents were given consecutively to compost aged 0, 10, 20, and 30 days. The comparison of straw and cow dung used namely 1: $1(\mathrm{~b} / \mathrm{b})$, and 10\% rumen contents. The Observations were done on the physical properties of compost, wet weight and dry weight of compost, and compost quality test on Zea mays germination. Based on the result of research, the giving of cow rumen contents at composting time affected the physical properties of compost, namely: temperature, humidity, and compost texture seen in P1-P4 $(P<0.05)$, however, $p H$ and compost color were the same. the wet weight and dry weight of compost were higher in the treatment which was given the cow rumen contents at P1-P4 $(P<0.05)$, however, the compost water content was the same. The giving of compost of rumen contents in Maize seeds could not increase the germination percentage and the height of Zea mays seeds. The quality of compost that given cow rumen contents was significantly better than compost without cow rumen contents.

Keywords: composting, cow rumen content, maize germination, organic fertilizer, physical quality 


\section{PENDAHULUAN}

Produktivitas ternak terutama
ruminansia sangat tergantung pada ketersediaan hijauan Indonesia merupakan negara yang sebagian besar penduduknya bertani. Sejak gerakan revolusi hijau, Indonesia juga ikut andil dalam mengembangkan pertanian terutama pertanian padi. Pada tahun 1984, Indonesia telah mampu melakukan swasembada pangan. Keberhasilan Indonesia dalam meningkatkan produksi padi tentu tidak terlepas dari pengembangan teknologi pupuk anorganik. Pengembangan pupuk anorganik memiliki dampak positif dan dampak negatif terhadap pertanian. Dampak positif dari penggunaan pupuk anorganik yaitu dapat meningkatkan produksi padi, sedangkan dampak negatif dari pupuk anorganik yaitu pencemaran lingkungan lahan pertanian dan inefisiensi pemupukan di sebagian besar daerah intensifikasi padi. Salah satu dampak pencemaran lahan pertanian akibat penggunaan pupuk anorganik yang berlebihan yaitu mengurangi aktifitas biologi tanah sehingga bisa menurunkan produksi tanaman padi (Bakrie et al., 2010). Untuk menanggulangi pencemaran akibat penggunaan pupuk anorganik maka pemerintah menggalakkan penggunaan pupuk organik.

Pupuk organik merupakan pupuk yang berasal dari bahan-bahan makhluk hidup atau makhluk hidup yang telah mati, meliputi kotoran hewan, serasah, sampah, dan berbagai produk antara dari organisme hidup (Sumekto 2006). Jenis- jenis pupuk organik yaitu pupuk kandang, pupuk hijau, bokashi, dan pupuk kompos (Purwendro dan Nurhidayat, 2007). Secara umum pupuk kompos diperoleh dari hasil pelapukan bahan-bahan tanaman atau limbah organik seperti jerami, sekam, daundaunan, rumput-rumputan, limbah organik pengolahan pabrik, dan sampah organik yang terjadi karena perlakuan manusia (Musnamar, 2009). Namun dalam proses pembuatan pupuk kompos tidak selalu menghasilkan kualitas kompos yang baik karena terdapat beberapa hal yang harus diperhatikan dalam pembuatan pupuk kompos, yaitu bahan yang digunakan, suhu dan ketinggian tumpukan bahan, serta kelembaban.

Bahan yang digunakan dalam pengomposan harus berukuran kecil dan tidak terlalu keras untuk mempercepat pelapukan. Selain itu, untuk mempercepat proses pengomposan biasanya menggunakan starter. Selama ini banyak proses pengomposan menggunakan EM4 komersil. Harga EM4 komersil cukup mahal dan jumlah bakteri yang terdapat di dalam kemasan akan semakin menurun jika disimpan cukup lama. Namun pembuatan pupuk hayati memerlukan biaya yang cukup tinggi. Untuk menyiasati hal tersebut maka bisa menggunakan isi rumen sapi sebagai alternatif untuk mempercepat proses pengomposan. Bakteri yang terdapat di dalam rumen sapi diduga dapat mempercepat pelapukan pada fermentasi limbah pathogen. Selain itu, mikroorganisme yang ada pada isi rumen sapi mampu meningkatkan jumlah unsur hara terutama kandungan nitrogen, mengendalikan penyakit dan menekan jumlah bakteri pathogen. Menurut Suripti (2012), pupuk kompos yang diberi pupuk hayati pada saat umur 20 hari pengomposan dapat meningkatkan kualitas kompos dan meningkatkan produksi tanaman jagung dan cabai.

Penggunaan isi rumen sapi masih belum banyak digunakan dalam proses pengomposan. Oleh karena itu, pemberian isi rumen sapi terhadap pembuatan pupuk kompos dan kualitas pupuk kompos yang dihasilkan masih perlu dikaji.

\section{METODE}

\section{Tempat Penelitian}

Penelitian ini dilaksanakan di kebun hijauan pakan ternak Program Studi Peternakan Fakultas Pertanian Universitas Madura. Waktu penelitian pada bulan Januari 2018 hingga September 2018. 


\section{Materi Penelitian}

Bahan penelitian yaitu jerami, kotoran sapi, isi rumen sapi, air, tanah, dan biji jagung.

\section{Pelaksanaan Penelitian}

Tahap Persiapan Pembuatan

Pupuk Kompos. Menyiapkan alat yang akan digunakan dalam proses pengomposan. Membuat bak atau kotak persegi empat yang terbuat dari papan kayu dengan lebar $1 \mathrm{~m}$ dan panjang $1 \mathrm{~m}$. Tinggi dari papan kayu tersebut $70 \mathrm{~cm}$. Selain itu, menyediakan terpal sebagai penutup bahan kompos saat pengomposan. Kemudian disiapkan bahan yang digunakan untuk kompos yaitu jerami, kotoran sapi, dan isi rumen sapi.

Tahap Pembuatan Pupuk Kompos. Pupuk organik kompos dibuat dari bahan jerami dan kotoran sapi dengan perbandingan 1:1 (b/b). Jerami dicacah dengan panjang sekitar 3-5 $\mathrm{cm}$ dan disusun secara berlapis dengan kotoran sapi pada bak kompos yang berukuran $1 \mathrm{mx} 1 \mathrm{~m}$. Bahan kompos yang telah dimasukkan ke bak kompos dimampatkan (dipadatkan), kemudian ditutup dengan terpal. Pada perlakuan P1, isi rumen sapi langsung diaplikasikan ke susunan jerami dan kotoran sapi, sedangkan pada perlakuan P2-P4 isi rumen sapi diaplikasikan berturut-turut pada umur 10, 20, dan 30 hari pada saat proses pengomposan. Pembalikan kompos dilakukan setiap 10 hari sekali. Setiap pembalikan kompos diberi air jika kompos terlalu kering. Kemudian kompos dibiarkan sampai matang dan dilakukan pengamatan.

Tahap Pemanenan Pupuk kompos. Kompos dipanen setelah kompos tersebut matang. Biasanya kompos dipanen sekitar 4045 hari. Secara umum ciri-ciri kompos yang sudah matang sebagai berikut: Tidak berbau, Berwarna kecoklat-coklatan sampai agak hitam, Tekstur mirip seperti tanah, suhunya tidak terlalu panas atau suhu sekitar $40^{\circ} \mathrm{C}$. kemudian dikeringanginkan selama \pm 3 hari atau hingga kering.

\section{Parameter Penelitian}

Parameter yang diamati yaitu, sifat fisik kompos yang diamati meliputi suhu kompos menggunakan termometer yang diamati setiap 5 hari sekali, kelembaban menggunaan Rh meter yang diamati setiap 5 hari sekali, $\mathrm{pH}$ kompos menggunakan kertas lakmus yang diamati pada akhir pengomposan, warna kompos yang diamati pada setiap pembalikan kompos (setiap 10 hari sekali), dan tekstur kompos yang diamati pada setiap pembalikan kompos (setiap 10 hari sekali).

Pengamatan juga dilakukan pada bobot basah dan bobot kering kompos, kadar air kompos, serta dilakukan Uji kualitas pupuk kompos pada perkecambahan jagung. Pada uji kualitas pupuk kompos ini dilakukan dengan cara mengaplikasikan pupuk kompos yang telah dikering anginkan pada biji jagung. Kemudian dilihat responnya.

\section{Rancangan Percobaan}

Penelitian ini dilakukan dengan metode percobaan (eksperimen) menggunakan Rancangan Acak Lengkap (RAL) dengan 5 perlakuan dan 3 ulangan, sehingga keseluruhan ada 15 percobaan. Perlakuan yang diberikan sebagai berikut: Kontrol (P0): jerami dan kotoran sapi tanpa isi rumen sapi, $\mathrm{P} 1$ : jerami dan kotoran sapi serta isi rumen diberikan pada kompos umur 0 hari, P2: jerami dan kotoran sapi serta isi rumen diberikan pada kompos umur 10 hari, P3: jerami dan kotoran sapi serta isi rumen diberikan pada kompos umur 20 hari, P4: jerami dan kotoran sapi serta isi rumen diberikan pada kompos umur 30 hari. Perbandingan jerami dan kotoran sapi yang digunakan yaitu $1: 1(\mathrm{~b} / \mathrm{b})$, serta $10 \%$ isi rumen sapi.

\section{Analisis Data}

Data dianalisis secara statistik menggunakan ANNOVA pada probabilitas $5 \%$. Software yang digunakan untuk analisis adalah program SPSS v.16.

\section{HASIL DAN PEMBAHASAN}

\section{A. Sifat Fisik Kompos}

Pengamatan sifat fisik kompos meliputi parameter suhu, kelembaban, $\mathrm{pH}$, tekstur 
Tabel 1. Rata-rata Suhu pada saat Pengomposan

\begin{tabular}{lcccccccc}
\hline & \multicolumn{7}{c}{ Hari ke- $\left({ }^{\circ} \mathrm{C}\right)$} \\
\cline { 2 - 8 } & 5 & 10 & 15 & 20 & 25 & 30 & 35 & 40 \\
\hline P0 & $35,67 \pm 1,52^{\mathrm{a}}$ & $34,00 \pm 2,00^{\mathrm{a}}$ & $37,33 \pm 0,57^{\mathrm{a}}$ & $46,33 \pm 1,52^{\mathrm{a}}$ & $42,67 \pm 2,52^{\mathrm{a}}$ & $44,33 \pm 5,13^{\mathrm{a}}$ & $40,67 \pm 0,57^{\mathrm{a}}$ & $35,00 \pm 1,00^{\mathrm{a}}$ \\
P1 & $39,67 \pm 0,58^{\mathrm{b}}$ & $36,33 \pm 1,15^{\mathrm{a}}$ & $37,00 \pm 1,00^{\mathrm{a}}$ & $51,00 \pm 2,00^{\mathrm{ab}}$ & $45,67 \pm 1,15^{\mathrm{a}}$ & $45,00 \pm 1,00^{\mathrm{a}}$ & $40,00 \pm 2,64^{\mathrm{a}}$ & $36,67 \pm 0,58^{\mathrm{a}}$ \\
P2 & $35,67 \pm 1,15^{\mathrm{a}}$ & $34,33 \pm 0,58^{\mathrm{a}}$ & $39,33 \pm 0,57^{\mathrm{b}}$ & $54,67 \pm 4,62^{\mathrm{b}}$ & $45,67 \pm 3,06^{\mathrm{a}}$ & $45,67 \pm 1,52^{\mathrm{a}}$ & $40,33 \pm 1,15^{\mathrm{a}}$ & $35,67 \pm 0,58^{\mathrm{a}}$ \\
P3 & $34,33 \pm 0,58^{\mathrm{a}}$ & $34,00 \pm 1,00^{\mathrm{a}}$ & $36,67 \pm 0,57^{\mathrm{a}}$ & $49,67 \pm 1,52^{\mathrm{a}}$ & $51,00 \pm 1,73^{\mathrm{b}}$ & $46,33 \pm 2,52^{\mathrm{a}}$ & $40,67 \pm 2,08^{\mathrm{a}}$ & $35,67 \pm 1,52^{\mathrm{a}}$ \\
P4 & $36,00 \pm 1,73^{\mathrm{a}}$ & $34,33 \pm 0,58^{\mathrm{a}}$ & $36,33 \pm 0,57^{\mathrm{a}}$ & $48,33 \pm 0,57^{\mathrm{a}}$ & $42,67 \pm 2,52^{\mathrm{a}}$ & $43,33 \pm 1,15^{\mathrm{a}}$ & $41,67 \pm 1,53^{\mathrm{a}}$ & $36,67 \pm 0,58^{\mathrm{a}}$ \\
\hline
\end{tabular}

Keterangan: Angka yang diikuti huruf yang berbeda menunjukkan berbeda nyata berdasarkan uji lanjut DMRT pada taraf kesalahan $\alpha=5 \%$.

Tabel 2. Rata-rata Kelembaban pada saat Pengomposan

\begin{tabular}{ccccccccc}
\hline & \multicolumn{7}{c}{ Hari ke- $(\%)$} \\
\cline { 2 - 8 } & 5 & 10 & 15 & 20 & 25 & 30 & 35 & 40 \\
\hline P0 & $62,33 \pm 0,58^{\mathrm{a}}$ & $61,00 \pm 2,65^{\mathrm{a}}$ & $65,33 \pm 0,58^{\mathrm{b}}$ & $64,00 \pm 1,00^{\mathrm{a}}$ & $65,00 \pm 2,65^{\mathrm{a}}$ & $65,00 \pm 1,00^{\mathrm{a}}$ & $64,33 \pm 0,58^{\mathrm{a}}$ & $53,33 \pm 1,15^{\mathrm{a}}$ \\
P1 & $64,67 \pm 0,58^{\mathrm{a}}$ & $65,67 \pm 0,58^{\mathrm{b}}$ & $65,33 \pm 0,58^{\mathrm{b}}$ & $65,33 \pm 0,58^{\mathrm{a}}$ & $65,33 \pm 1,53^{\mathrm{a}}$ & $66,00 \pm 1,73^{\mathrm{a}}$ & $65,33 \pm 0,58^{\mathrm{a}}$ & $56,00 \pm 3,46^{\mathrm{a}}$ \\
P2 & $63,00 \pm 2,00^{\mathrm{a}}$ & $58,67 \pm 2,08^{\mathrm{a}}$ & $66,67 \pm 0,58^{\mathrm{c}}$ & $68,33 \pm 1,15^{\mathrm{b}}$ & $65,33 \pm 0,58^{\mathrm{a}}$ & $65,33 \pm 1,15^{\mathrm{a}}$ & $65,3 \pm 30,58^{\mathrm{a}}$ & $55,33 \pm 4,93^{\mathrm{a}}$ \\
P3 & $62,67 \pm 2,31^{\mathrm{a}}$ & $60,33 \pm 1,53^{\mathrm{a}}$ & $64,67 \pm 0,58^{\mathrm{b}}$ & $65,67 \pm 2,08^{\mathrm{a}}$ & $70,00 \pm 1,73^{\mathrm{b}}$ & $67,33 \pm 1,53^{\mathrm{a}}$ & $65,00 \pm 1,00^{\mathrm{a}}$ & $54,00 \pm 1,00^{\mathrm{a}}$ \\
P4 & $62,00 \pm 1,00^{\mathrm{a}}$ & $60,00 \pm 2,65^{\mathrm{a}}$ & $63,33 \pm 0,58^{\mathrm{a}}$ & $65,00 \pm 1,00^{\mathrm{a}}$ & $65,33 \pm 2,31^{\mathrm{a}}$ & $66,33 \pm 2,31^{\mathrm{a}}$ & $67,00 \pm 1,00^{\mathrm{b}}$ & $55,33 \pm 2,31^{\mathrm{a}}$ \\
\hline
\end{tabular}

Keterangan: Angka yang diikuti huruf yang berbeda menunjukkan berbeda nyata berdasarkan uji lanjut DMRT pada taraf kesalahan $\alpha=5 \%$.

kompos, dan warna kompos.

\section{Suhu Kompos}

Berdasarkan pengamatan dari semua perlakuan, suhu naik dari awal pengomposan kemudian turun diakhir pengomposan (Tabel 1). Kenaikan suhu pengomposan dimulai pada hari ke-15 sampai hari ke-25 proses pengomposan yaitu $39,33-51,00^{\circ} \mathrm{C}$. Suhu maksimum pada proses pengomposan yaitu $45-60^{\circ} \mathrm{C}$. Suhu yang tinggi pada saat pengomposan merupakan akibat dari aktivitas mikroba termofilik dalam tumpukan bahan kompos. Fungsi mikroba ini yaitu mengkonsumsi karbohidrat dan protein yang terkandung dalam bahan kompos, sehingga bahan baku kompos terdegradasi dengan cepat (Widawati, 2005). Menurut Rynk (1992), suhu yang berkisar antara $30-60^{\circ} \mathrm{C}$ menunjukkan aktivitas pengomposan yang cepat. Namun jika suhu tersebut lebih tinggi dari $60^{\circ} \mathrm{C}$ maka akan membunuh sebagian mikroba dan hanya mikroba thermofilik saja yang akan tetap bertahan hidup.

Suhu pada P1 tinggi pada hari ke-5 pengomposan yaitu $39,67^{\circ} \mathrm{C}$ karena pada awal pengomposan (hari ke-0) sudah di aplikasi isi rumen sapi. Berdasarkan uji $\mathrm{F}$ Kenaikan suhu pada P1 hari ke-5 nyata lebih tinggi dibandingkan perlakuan yang lain. Suhu P2 tinggi pada hari ke- 15 yaitu $39,33^{\circ} \mathrm{C}$ karena pada saat pembalikan di hari ke -10 diaplikasikan isi rumen sapi. Berdasarkan uji F Kenaikan suhu pada P2 hari ke-15 nyata lebih tinggi dibandingkan perlakuan yang lain. Suhu P3 tinggi pada hari ke-25 yaitu $51^{\circ} \mathrm{C}$ karena pada hari ke-20 diaplikasikan rumen sapi. Berdasarkan uji F Kenaikan suhu pada P3 hari ke-25 nyata lebih tinggi dibandingkan perlakuan yang lain. Sedangkan suhu P4 pada hari ke-35 yaitu $41^{\circ} \mathrm{C}$ hampir sama dengan suhu perlakuan yang lain walaupun diaplikasikan rumen sapi pada hari ke-30. Berdasarkan uji F, suhu pada P4 hari ke-35 tidak berbeda nyata dengan perlakuan yang lain. 
Pemberian isi rumen sapi mempengaruhi suhu pengomposan. Hal tersebut terlihat saat diberi isi rumen sapi suhu kompos semakin meningkat. Pada rumen sapi terdapat mikroorganisme selulotik yang hidup pada suhu $39-40^{\circ} \mathrm{C}$ (Thalib et al., 2000).

\section{Kelembaban Kompos}

Dari semua perlakuan, kelembaban naik dari awal pengomposan kemudian turun diakhir pengomposan (Tabel 2). Puncak kenaikan kelembaban yaitu pada hari ke15 sampai hari ke-30 proses pengomposan. Hal itu terjadi karena suhu pengomposan meningkat sehingga kelembaban kompos juga meningkat. Kelembaban pada P1 hari ke-5 pengomposan lebih tinggi dibandingkan kontrol dan perlakuan yang lain. Berdasarkan uji F, kelembaban pada P1 hari ke-5 nyata lebih tinggi dibandingkan perlakuan yang lain. Hal itu terjadi karena sudah diaplikasikan isi rumen sapi pada hari ke-0 pengomposan. Kelembaban P2 lebih tinggi dibandingkan dengan kontrol dan perlakuan yang lain pada hari ke-15 sampai hari ke-20. Berdasarkan uji F, kelembaban pada P2 hari ke-15 nyata lebih tinggi dibandingkan perlakuan yang lain karena pada saat pembalikan di hari ke-10 di aplikasikan isi rumen sapi.

Kelembaban P3 naik pada hari ke-25 yang didukung oleh hasil uji F. Berdasarkan uji $F$, kelembaban pada hari ke-25 nyata lebih tinggi dibandingkan perlakuan yang lain karena pada saat pembalikan pada hari ke-20 diaplikasikan rumen sapi. Begitu juga kelembaban P4 naik pada hari ke-35 dan lebih tinggi dibandingkan dengan kontrol dan perlakuan yang lain. Berdasarkan uji $\mathrm{F}$, kelembaban pada hari ke-35 nyata lebih tinggi dibandingkan perlakuan yang lain karena diaplikasikan isi rumen sapi pada hari ke-30.

Pada akhir pengomposan kelembaban pengomposan turun pada semua perlakuan. Menurut Widarti et al. (2015), penurunan kelembaban disebabkan karena aktivitas mikroorganisme yang menggunakan air untuk proses kelangsungan hidupnya guna melakukan proses dekomposisi. Kelembaban
40-60\% adalah kisaran optimum untuk metabolisme mikroba.

Pemberianisirumen sapimempengaruhi kelembaban pengomposan. Hal tersebut terlihat saat diberi isi rumen sapi kelembaban kompos semakin tinggi dibandingkan dengan kontrol. Menurut Widarti et al. (2015) kelembaban memegang peranan yang sangat penting dalam proses metabolisme mikroba dan secara tidak langsung berpengaruh pada suplai oksigen. Jika kelembaban terlalu rendah, efisiensi degradasi akan menurun karena kurangnya air untuk melarutkan bahan organik yang akan didegradasi oleh mikroorganisma sebagai sumber energinya.

\section{3. pH Kompos}

Pemberian isi rumen sapi sedikit mempengaruhi $\mathrm{pH}$ pengomposan. Namun berdasarkan analisis statistik yaitu uji $\mathrm{F}, \mathrm{pH}$ pada semua perlakuan tidak berbeda nyata (Tabel 3).

Tabel 3. Rata-rata pH Kompos

\begin{tabular}{lc}
\hline Perlakuan & $\mathrm{pH}$ \\
\hline P0 & $6,7 \pm 0,58$ \\
P1 & $6,7 \pm 0,58$ \\
P2 & $6,3 \pm 0,57$ \\
P3 & $6,3 \pm 0,57$ \\
P4 & $6,0 \pm 0,10$ \\
\hline
\end{tabular}

Berdasarkan pengamatan bahwa saat diberi isi rumen sapi $\mathrm{pH}$ kompos sedikit menurun. Menurut penelitian Maradhy (2009), kisaran $\mathrm{pH}$ optimum pada proses pengomposan yaitu 6-7,5. Senyawa asamasam organik akan terbentuk pada proses awal pengomposan. Kondisi asam tersebut akan memicu pertumbuhan jamur yang akan mendekomposisi lignin dan selulosa yang terkandung di dalam serasah sehingga akan menjadi pupuk kompos.

\section{Warna Kompos}

Pemberian isi rumen sapi tidak mempengaruhi warna kompos, terlihat pada semua perlakuan warna kompos sama (Tabel 4). Namun, berdasarkan pengamatan warna kompos mengalami perubahan dari awal 
Tabel 4. Parameter Warna pada saat Pengomposan

\begin{tabular}{lcccc}
\hline \multirow{2}{*}{ Perlakuan } & \multicolumn{4}{c}{ Hari ke- } \\
\cline { 2 - 5 } & coklat muda & coklat sedikit tua & coklat tua & coklat kehitaman \\
\hline P0 & coklat muda & coklat sedikit tua & coklat tua & coklat kehitaman \\
P1 & coklat muda & coklat sedikit tua & coklat tua & coklat kehitaman \\
P2 & coklat muda & coklat sedikit tua & coklat tua & coklat kehitaman \\
P3 & coklat muda & coklat sedikit tua & coklat tua & coklat kehitaman \\
\hline
\end{tabular}

Tabel 5. Parameter Tekstur pada saat Pengomposan

\begin{tabular}{lcccc}
\hline \multirow{2}{*}{ Perlakuan } & \multicolumn{4}{c}{ Hari ke- } \\
\cline { 2 - 5 } & 10 & 20 & 30 & 40 \\
\hline P0 & kasar & sedikit kasar & agak halus & halus \\
P1 & kasar & agak halus & halus & lebih halus \\
P2 & kasar & agak halus & halus & lebih halus \\
P3 & kasar & sedikit kasar & halus & lebih halus \\
P4 & kasar & sedikit kasar & agak halus & lebih halus \\
\hline
\end{tabular}

pengomposan sampai akhir pengomposan yaitu dari coklat muda pada hari ke-10, selanjutnya berubah menjadi coklat sedikit tua pada hari ke-20, kemudian berubah menjadi coklat tua pada hari ke-30 dan menjadi coklat kehitaman pada hari ke-40 yang artinya bahwa kompos tersebut sudah matang.

Perubahan warna kompos dari coklat menjadi coklat kehitaman menunjukkan adanya bakteri dan jamur yang melakukan aktivitas dekomposisi, sehingga mampu mengubah warna kompos. Perubahan warna tersebut disebabkan oleh hilangnya nitrogen yang diakibatkan karena proses dekomposisi yang terjadi di dalam pengomposan.

Gaur (1986) menyatakan bahwa panas yang dihasilkan pada proses pengomposan mampu memecah ikatan lignin sehingga nitrogen menjadi berkurang. Hal tersebut menyebabkan warna berubah menjadi coklat dan pengomposan menuju ke fase pematangan. Selama proses pengomposan akan terjadi penguraian bahan organik oleh aktivitas mikroba, yaitu mikroba akan menkonsumsi air, oksigen dan nutrisi dari bahan organik yang kemudian akan mengalami penguraian dan membebaskan $\mathrm{CO} 2$ dan $\mathrm{O} 2$.

\section{Tekstur Kompos}

Pemberian isi rumen sapi hanya sedikit mempengaruhi tekstur kompos, terlihat bahwa tekstur kompos yang diberi rumen sapi lebih halus dibandingkan dengan kontrol pada semua perlakuan (Tabel 5).

Menurut Kusmiyarti (2013) proses dekomposisi yang dilakukan oleh mikroba akan menguraikan senyawa-senyawa organik yang terdapat dalam bahan kompos, sehingga bahan akan menjadi remah dan strukturnya menjadi lebih halus.

\section{B. Bobot Basah, Bobot Kering dan Kadar Air Kompos}

Berikut ini merupakan hasil pengamatan kompos dilihat dari bobot basah, bobot kering, dan kadar air kompos yang diamati setelah pemanenan kompos (Tabel 6). Berdasarkan hasil uji statistik yaitu uji $\mathrm{F}$ menunjukkan bahwa bobot basah kompos yang diberi rumen pada semua perlakuan P1P4 nyata lebih tinggi dibandingkan dengan kontrol. Namun, Bobot basah kompos tidak berbeda nyata pada semua perlakuan P1, P2, P3, dan P4. Begitu juga dengan bobot kering kompos, hasil uji statistik yaitu uji $\mathrm{F}$ 
Tabel 6. Rata-rata Bobot Basah, Bobot Kering, dan Kadar Air

\begin{tabular}{lccc}
\hline \multirow{2}{*}{ Perlakuan } & \multicolumn{3}{c}{ Parameter } \\
\cline { 2 - 4 } & Berat Basah Kompos (kg) & Berat Kering Kompos (kg) & Kadar Air (\%) \\
\hline P0 & $72,33 \pm 0,58^{\mathrm{a}}$ & $51,33 \pm 1,15^{\mathrm{a}}$ & $40,67 \pm 3,05$ \\
P1 & $78,67 \pm 0,58^{\mathrm{b}}$ & $56,00 \pm 1,00^{\mathrm{b}}$ & $40,00 \pm 1,73$ \\
P2 & $78,33 \pm 0,58^{\mathrm{b}}$ & $57,33 \pm 0,58^{\mathrm{b}}$ & $36,00 \pm 0,00$ \\
P3 & $78,33 \pm 0,58^{\mathrm{b}}$ & $57,33 \pm 1,15^{\mathrm{b}}$ & $36,33 \pm 2,52$ \\
P4 & $79,00 \pm 1,00^{\mathrm{b}}$ & $57,33 \pm 0,58^{\mathrm{b}}$ & $37,33 \pm 2,31$ \\
\hline
\end{tabular}

Keterangan: Angka yang diikuti huruf yang berbeda menunjukkan berbeda nyata berdasarkan uji lanjut DMRT pada taraf kesalahan $\alpha=5 \%$.

Tabel 7. Persentase Perkecambahan Biji Jagung setelah diaplikasi Kompos Isi Rumen

\begin{tabular}{lcc}
\hline Perlakuan & Persen kecambah hari ke 4 & Persen Kecambah hari ke 8 \\
\hline P0 & $67 \pm 0,00$ & $76,5 \pm 4,95$ \\
P1 & $80 \pm 9,89$ & $93,5 \pm 9,19$ \\
P2 & $80 \pm 0,00$ & $90 \pm 4,24$ \\
P3 & $80 \pm 18,38$ & $90 \pm 14,14$ \\
P4 & $66,5 \pm 9,19$ & $80 \pm 0,00$ \\
\hline
\end{tabular}

menunjukkan bahwa bobot kering kompos yang diberi rumen pada semua perlakuan P1P4 nyata lebih tinggi dibandingkan dengan kontrol. Namun, Bobot kering kompos tidak berbeda nyata pada semua perlakuan P1, P2, P3, dan P4. Hal ini karena pada perlakuan P1P4 diaplikasi isi rumen sapi dengan takaran yang sama yaitu $10 \%$ dari bobot jerami dan kotoran sapi. Hasil uji F menunjukkan bahwa kadar air kompos tidak berbeda nyata pada semua perlakuan.

Kadar air dapat berpengaruh terhadap aktivitas mikroorganisme dalam mendekomposisikan bahan organik. Kandungan air dibawah $30 \%$ reaksi biologis akan berjalan lambat dan dapat mengakibatkan berkurangnya populasi mikroorganisme pengurai karena terbatasnya habitat yang ada. Kadar air yang terlalu tinggi menyebabkan ruang antar partikel menjadi penuh oleh air, sehingga mencegah gerakan udara dalam tumpukan dan hambatan aktivitas mikroorganisme, sehingga menimbulkan bau. Menurut SNI kompos kadar air maksimal $50 \%$ sedangkan batas minimalnya tidak ada
(SNI, 2004).

\section{Uji Kualitas Kompos pada Perkecambahan Jagung}

Berdasarkan hasil pengamatan menunjukkan bahwa persentase perkecambahan jagung lebih tinggi pada kompos yang diberi isi rumen sapi (P1-P4) dibandingkan dengan kontrol pada hari k-4 dan ke-8 (Tabel 7). Namun berdasarkan uji F, persentase perkecambahan tidak menunjukkan perbedaan nyata antar perlakuan.

Nilai persen kecambah di atas 80 menunjukkan bahwa kompos yang dihasilkan tidak berpotensi toksik pada tanaman (Kusmiyarti, 2013). Hal ini menunjukkan bahwa kompos yang dihasilkan sudah cukup matang dan aman untuk digunakan pada tanaman.

Berdasarkan hasil pengamatan menunjukkan bahwa tinggi benih jagung lebih tinggi pada kompos yang diberi isi rumen sapi (P1-P4) dibandingkan dengan kontrol pada hari k-4 dan ke-8 (Tabel 8). Namun berdasarkan uji F, tinggi benih jagung tidak menunjukkan perbedaan nyata 
Tabel 8. Tinggi Benih Jagung setelah diaplikasi Kompos Isi Rumen

\begin{tabular}{lcc}
\hline Perlakuan & Tinggi hari ke 4 & Tinggi hari ke 8 \\
\hline P0 & $6 \pm 2,82$ & $13,0 \pm 5,65$ \\
P1 & $9 \pm 0,00$ & $18,0 \pm 1,41$ \\
P2 & $7 \pm 0,00$ & $14,5 \pm 0,71$ \\
P3 & $8 \pm 1,41$ & $16,0 \pm 2,83$ \\
P4 & $8 \pm 1,41$ & $16,0 \pm 2,83$ \\
\hline
\end{tabular}

antar perlakuan. Hal tersebut diduga karena pengamatan yang dilakukan terhadap tinggi benih hanya dilakukan selama 8 hari.

\section{KESIMPULAN}

Pemberian isi rumen sapi pada saat pengomposan mempengaruhi sifat fisik dari kompos yaitu suhu, kelembaban, dan tekstur kompos. Namun untuk pH dan warna kompos sama. Bobot basah dan bobot kering kompos lebih tinggi pada perlakuan yang diberi isi rumen sapi. Namun kadar air kompos sama. Pemberian kompos isi rumen pada biji jagung tidak dapat meningkatkan persentase perkecambahan biji jagung dan tinggi benih jagung. Kompos yang diberi isi rumen sapi lebih bagus kualitasnya dibandingkan dengan kompos tanpa isi rumen sapi.

\section{UCAPAN TERIMAKASIH}

Terimakasih kepada LLDIKTI yang telah mendanai penelitian ini. Terimakasih kepada LPPM Universitas Madura atas dukungan yang telah diberikan guna penyelesaian penelitian ini.

\section{DAFTAR PUSTAKA}

Bakrie, M. M., Anas, I. dan Sugiyanta, Komaruddin. 2010. Aplikasi pupuk anorganik dan organik hayati pada budidaya padi SRI (System of Rice Intensification). J. Tanah Lingk. 12 (2): 25-32.
Gaur, A. C. 1986. A Manual of rural Composting. FAO/UNDP Regional Project Divition of Microbiology. Agriculture Institute. New Delhi. Indian.

Kusmiyarti, T. B. 2013. Kualitas kompos dari berbagai bahan baku limbah organik. Agrotrop 3(1): 83-92

Maradhy, E. 2009. Aplikasi campuran kotoran ternak dan sedimen mangrove sebagai aktivator pada proses dekomposisi limbah domestik. [Tesis]. Pascasarjana Universitas Hasanuddin. Makassar.

Musnamar, E. I. 2009. Pupuk Organik: Cair dan Padat, Pembuatan, Aplikasi. Jakarta: Penebar Swadaya.

Purwendro, D. dan Nurhidaya, T. 2007. Pembuatan Pupuk Cair. Jakarta: Gramedia Pustaka Utama.

Rynk, R. 1992. On-Farm Composting Handbook. Northeast Regional Agricultural Engineering Service. Ithaca: Cornell University.

SNI (Standar Nasional Indonesia). 2004. Spesifikasi kompos dari sampah organik domestik. 19-7030.

Sumekto, R. 2006. Pupuk Organik. Klaten: Intan Sejati.

Suripti, S. 2012. Respon fisiologi tanaman jagung dan cabai terhadap aplikasi pupuk organik yang diperkaya dengan pupuk hayati pada dua lokasi pengujian yang berbeda. [Tesis]. Bogor: Institut Pertanian Bogor

Thalib A, B. Haryanto, S. Kompiang, I.W. Mathius, dan A. Aini. 2000. Pengaruh mikromineral dan fenilpropionat 
terhadap performans bakteri selulolitik cocci dan batang dalam mencerna serat hijauan pakan. J. Ilmu Ternak Vet. 5(2): $92-99$

Widawati, S. 2005. Daya pacu aktivator fungi asal Kebun Biologi Wamena terhadap kematangan hara kompos, serta jumlah mikroba pelarut fosfat dan penambat nitrogen. Biodiversitas 6 (4): 240-243.

Widarti, B. N., Wardah, K. W. dan Edhi, S. 2015. Pengaruh rasio $\mathrm{C} / \mathrm{N}$ bahan baku pada pembuatan kompos dari kubis dan kulit pisang. Jurnal Integrasi Proses 5 (2): 75-80. 